\title{
The Son's Room
}

\author{
By John Izod, Joanna Dovalis
}

Spring 2012 Issue of KINEMA

\section{PHYSICIAN, HEAL THYSELF: THE SON'S ROOM}

Although we know that after such a loss the acute state of mourning will subside, we also know we shall remain inconsolable and will never find a substitute. No matter what will fill the gap, even if it be filled completely, it nevertheless remains something else. And actually this is how it should be. It is the only way of perpetuating that love which we do not want to relinquish.

Sigmund Freud, Letter to Ludwig Binswanger (1929)

PHILIP FRENCH makes the point that La Stanza del Figlio (the Italian title of The Son's Room) carries a pun. In addition to 'the room' explicit in the English version, stanza also means a verse in both languages, thus suggesting the idea of 'a poem or part of a life left standing' (2002). In this pun lies the key to what makes the film special. On the one hand it deals with the lives of an ordinary, educated middle-class family, the Sermontis; on the other, it does so with a quiet approach that achieves its impact through a restrained script and performances by the five leads so sensitive that irresistibly they command viewers' empathy. Peter Bradshaw astutely observes, 'the essential happiness of their bourgeois existence is the happiness that, in the Russian phrase, writes white on the page. Its unassuming contentment is all but invisible' (2002). Bradshaw rightly implies that the film leaves such memories; but that is all the more interesting in that we are almost from the beginning led into a devastating crisis that could have resulted in the fragmentation of a family.

Giovanni Sermonti (Moretti) is established as a healthy man who runs to take care of himself (both physically and emotionally) and to balance the long hours he spends with clients in practice as a psychoanalyst. He jogs along the harbour past cargo ships owned by Costa Container Lines - it's a real company but its name provides a metaphor for Giovanni's role as a therapist and also anticipates problems he will face. Psychologically organised to provide a container for other people's emotional worlds, in his personal life he will prove so self-contained as to make it extremely difficult to be vulnerable when he most needs others. Since Costa is Italian for coast, the full name may hint at the position he will find himself in, on the edge.

Giovanni is called urgently to a meeting at his son's school where his boy, seventeen year-old Andrea (Giuseppe Sanfelice), has been accused of colluding with another lad to steal a fossil from a science laboratory. Although Andrea denies the allegation, the Head Teacher believes that he has sufficient evidence to prove his guilt and suspends him for a week. Despite this, the love and strong family rituals that bond the Sermontis are not disturbed. The parents have the capacity to respond to their children's emotional needs and provide a safe holding environment which encourages growth, maturity and testing of limits even in the face of the uncomfortable allegation. Giovanni, his beautiful wife Paola (Laura Morante), their daughter Irene (Jasmine Trinca) and Andrea continue to gather at meal times and enjoy each other's company. We cannot but notice, however, that Paola's unconditional maternal love (she faithfully believes her son's innocence) differs from the necessarily more objective, conditional stance of the father which serves to guide his teenagers into adulthood.

The parents pay attention to issues as they impinge rather than allowing problems to go underground another sign of a thriving family. The evening after his son's exclusion from school, Giovanni takes Andrea to a meeting between the families concerned. One boy had told the Head Teacher that he saw the missing ammonite in the bag of Andrea's friend who has also been suspended. The father of this last boy puts pressure on the accuser until he retracts. The issue seems resolved except that something causes Giovanni unease. He says he feels the other father has been too aggressive, but as the days pass it becomes clear that he has private doubts about Andrea's innocence - doubts that he does not voice to his son.

Notwithstanding the school incident, the family remain by and large well attuned to each other. One evening, for example, Giovanni and Paola help Irene with some tricky Latin homework. And it is not only the parents who are aware of their young. Irene observes her father's body language after Andrea's suspension from school. 
Realising that her father is not wholly convinced of his son's innocence, she teases Giovanni into sharing her own good humour. Her sensitive reading of his discomfort suggests that she recognises her father's anxiety.

Giovanni is a kind, if slightly weary psychoanalyst with a clientele who keep him fully occupied. His counselling room is reached from the family apartment. Opening the double doors that lead into the office is a weekday morning ritual since they mark the liminal psychological and emotional boundary between his very connected home environment and the pain-filled emotional lives of his patients. Such are the obsessions of those coming for therapy that they make it hard for us to think of the family as anything but blissfully content - and normal. Giovanni bears the heavy weight of his profession the more willingly because in the evening the quiet ceremony of switching off the lights mirrors that first moment of the day as, with growing pleasure, he returns to the warmth of family. His devoted service to his clients is amplified by the stability of his loving and connected family. In this respect, he and Paola are alike, both having a passion for their work. They differ in that her career as a publisher not only gives her a fulfilling independent professional life but something she can share enthusiastically with her husband; by contrast Giovanni's career must be kept to himself.

The separation of Giovanni's family life from the long hours he spends with his clients is significant because he has to keep the lives of those on either side of the double doors apart. In the consulting room, skilled therapists allow themselves an essential vulnerability in order to create an internal environment fully impacted by the patient's experience, while simultaneously holding their own mind and self boundary as they help the client to mentalize. ${ }^{(1)}$ It is this most rigorous component of the therapeutic process that we will come to see Giovanni must confront. Giovanni does take his clients' worlds in but not until, after his son's death when he announces he is closing his practice, can he allow himself to let go and make physical contact with a client who desperately needs connection. When this angry man rages against the abandonment he feels, Giovanni hugs him, an authentic moment of real contact which signals the psychotherapist's own defences breaking down at last and releasing unresolved grief for both of them.

Although he has patients who have deep-rooted traumas, the majority of Giovanni's clients suffer neuroses to which the prosperous middle-aged, middle classes are prone - paying the price, as George Boeree (2002), says for 'poor ability to adapt to one's environment, an inability to change one's life patterns, and the inability to develop a richer, more complex, more satisfying personality.' One woman comes week after week to share the anguish of having to make decisions - any decisions. Another gnaws bitterly at the uselessness of the therapy she receives, heaves a sigh of pleasure when she has puked up this nasty mental hairball and leaves, promising cheerfully to return in a week's time, when (as her analyst notes) she will neurotically repeat. A no less derisive client expunges the ravaging memories of her sessions (blighted, she wrongly believes, by Giovanni's failure to understand her) by profligate shopping (a routine excess for which, naturally, she blames him). All these malades imaginaires verge on the ludicrous, blind (when viewed superficially) to their self-indulgence. Apart from these, emotionally struggling individuals come for help and Giovanni offers such reflections as they are able to take in. For example, he advises a patient who feels excessive guilt that he should try not to control everything but learn to relish idleness and thus reduce anxiety.

And then there are the more serious personality disorders. A man addicted to child pornography and promiscuous sex with prostitutes both male and female appears to have made some progress; but when Giovanni congratulates him the client is instantly caught in a complex and overwhelmed by guilt and shame. He unleashes pent-up anger and furiously describes a scenario of dangerous sexual exhibitionism to which he is drawn. Analytic mistakes are inevitable and Giovanni's response has ignited a transference neurosis, releasing the patient's bad objects from his unconscious - one of the most difficult processes of therapy. As part of the healing process, whatever happens outside the therapy room needs to be re-enacted in the room between the therapist and patient, a process known as "acting in" rather than "acting out". Giovanni, however, appears neither to have intended nor anticipated the event: at times driven too much by his own super-ego construct, his limitations blind him. Yet the more a therapist is aware of what is going on inside himself, the more he is able to access all parts of himself, making conscious therapeutic interventions which connect the client to his own inner life with the aim of getting unstuck from old psychic patterns.

Among Giovanni's patients there are those who naturally reflect parts of his personality, some of which are patent, but others still hiden. The woman who complains of boredom cannot see from her place on the 
couch that transference is occurring. She inflicts boredom on him to the extent that he fantasises showing her all the many shoes he keeps for the sports he enjoys. If only, rather than keeping his fantasies mute, he were able to use them as part of the therapeutic process (as his supervisor suggests regarding a different client), movement might occur. The excessively guilty patient who tries to control everything foreshadows Giovanni's ungovernable attempts to turn the clock back after Andrea dies: as the therapist he seems unable to demonstrate what he has told this client. Finally, the traumatised patient's abandonment tantrum resembles Giovanni breaking damaged crockery when feeling abandoned through his son's death.

Another patient, sad Oscar (Silvio Orlando), brings dreams to the analyst's couch. In one, people quitting a party leave him alone in a large building; but before Giovanni can investigate the dream with him he defensively dismisses it - and the analysis - as boring. When another nightmare confronts Oscar with a ship of the dead, he insists all is well despite thoughts of a renewed attempt at suicide. Although hindsight reveals that Oscar's dreams forewarn him of his future, Giovanni finds it hard to pierce this patient's defences to work with him. Yet the mysterious parallel process that sometimes takes place between client and therapist appears once again to be occurring here in that Oscar's dream bears not only on his own life but also Giovanni's since the ship of the dead foretells the fate that is closing in on him.

All these cases, which we join in medias res, appear wretchedly intractable. No matter that Giovanni practises in the small Italian coastal city of Ancona, his clientele seem little different from those who might be expected to visit psychoanalysts anywhere in Western Europe or North America.

Giovanni cannot quite set aside his worries about his son, doubtful that he is acting as a normal boy of his age should. When Andrea enters a tennis tournament, Giovanni is deeply bothered by the adolescent's relaxed attitude in playing so casually that he loses. An intuitive and psychological man, Giovanni is aware that a competitive spirit contributes to developing a sense of mastery and control. Andrea finds his father's sporting competitiveness amusing because he himself plays casually for pleasure. Despite the close affection between them, their personality differences are apparent here. Father and son do not relate in their attitudes toward competition and need for control.

Giovanni is almost always so emotionally contained that he may be difficult to reach in a deeply felt way. It fits with Andrea's psychology that, as an adolescent boy who identifies with his father and seeks his approval, rather than disturb a shared moment when his father is feeling happy, the boy confesses instead to his mother that he and a friend did take the ammonite. They had meant only to play a trick on a teacher, but before they could return the stone, they dropped and smashed it. Although a typical adolescent prank, the joke may have undertones of father transference as Andrea's attempt to elicit from the science teacher an emotional response difficult to get from his father. As we have seen, Andrea, perhaps by way of compensation, is interested in playing: his attitude toward games has more to do with connection than opposition. Contrary to his father's frequent isolation in private practice, he is surrounded by male companions.

When Andrea confesses to his mother, Paola reacts by asking a few pointed questions and then gives her boy an affectionate hug. She offers the unconditional love which, since the father has to prepare the children for the external world, he archetypally cannot. All the same, Giovanni's stoicism seems to have preceded the nurturing of his offspring. Not uncommon to the personality of the therapist, it may stem from his own personal history to be emotionally so well contained.

Moretti keeps us focussed on the family and we never find out what happens at the school. Come Sunday morning, Giovanni wants to show his affection for Andrea and asks him to go running. He repeatedly ruffles his son's hair as if to reassure the lad that, despite the debacle with the ammonite, he is secure in his father's love. But beneath this obvious motivation there appears to lie his own natural need to feel connected to his family.

Despite this, as a therapist Giovanni struggles with the conflict between his own needs and those of others. And for that reason the run never happens. Oscar telephones while the Sermontis are still at breakfast, so distraught that he claims he cannot wait for his next appointment. Giovanni, rather than transfer the call to his office, answers from the kitchen, breaking the physical boundary that helps him separate work and family. Rather than fully assessing his patient as a suicide risk and responding accordingly, he reacts from his own anxieties. Psychologically organised to respond to the needs of others, he is unable to hold the internal 
tension projected inside him. He gives way to his patient's intense sense of urgency which takes precedence over pleasure-seeking and his need for connection with Andrea. Submitting to feelings of responsibility, he agrees reluctantly to make an immediate house call. This is at the cost of disappointing his family - possibly a familiar dynamic faced by the Sermontis.

As he drives out of town, the family occupy themselves in different pursuits, yet each experiences a memento mori, a reminder that existence is tenuous (Armstrong, 2001). At an antiques street market a thief escaping pursuit barges into Paola. Irene, on her scooter, fends off some crazy friends who ride alongside and kick out at her machine for fun. Both moments are synecdochic, miniature forewarnings of the ruin that sooner or later impinges on every human life. They hint too at the discernment necessary to respond consciously in times of decision when the shadow may be present. Meanwhile Giovanni listens to Oscar who has been diagnosed with lung cancer and is certain he will die.

In the late afternoon Giovanni returns home and is met at his door by weeping friends who break the news of calamity. Andrea has drowned while scuba diving. In complete shock, Giovanni goes to a basketball hall to find Irene. There she is, playing in a match, running blithely in complete control of the ball. She grins at her dad with pride before registering his traumatised face. Horror freezes her to the spot. An opponent steals the ball and both teams sweep back past her as if she were no longer there - which to all intents and purposes is true.

In their first paroxysms of anguish, during the immediate hours after Andrea drowns, the three survivors weep together. As non-believers in a Catholic nation, they have no rituals for taking leave of Andrea. There is no funeral ceremony. Instead, in a harrowing scene, they are constrained to watching in the hospital morgue as impassive undertakers seal the beautiful young man in his coffin. They will never see him again.

Soon the grief of the surviving family members pulls them in different directions. The devastating isolation of bereavement: all the rituals that have bonded them as a family break down. For example, although Irene tries to keep the old patterns alive, they no longer gather round the table at mealtimes. For want of an alternative secular ritual, she proposes the family should ask for a Mass to be said so that Andrea's friends have somewhere to commemorate him. Her parents agree, but the memorial is a ghastly affair. A priest who knows nothing about Andrea doles out the dogmatic bromides of a sclerotic faith, adding to the family's wretchedness. Here we have a paradox: a warm family engaged in its own daily rituals which create a deep sense of connection is confronted by a lack of connection to a spiritual life which ought to have the power to provide a larger container for a loss of such magnitude. The disjunction echoes the start of the film when Giovanni watches a group of Hari Krishna dancers going through the streets, puzzled by what they are doing. Yet Giovanni's stupefied anger deafens him to the potent resonances of the priest's words when heard psychologically: they are a reminder that the marriage of the psychological and spiritual completes the self. The priest intones,

If the master of the house had known in what hour the thief was coming, he would have watched, and not have left his house to be broken through. (Luke 12:39)

In raising the biblical metaphor of theft, the priest draws the authorised moral that we cannot know when God will come for us. This for Giovanni is so inapposite that he rages against it. Yet theft has become a motif (Andrea and the ammonite; the moment at the market; the ball stolen on the field of play from Irene; Andrea's life stolen from him; the lad snatched away from the survivors). Furthermore, switching registers, Giovanni is the master of the house, unconscious of the shadow consequences of the choice he made by reacting to his patient's cry for help and breaking the agreement to go running with his son. That, psychologically speaking, left his home vulnerable to potential loss - a spiritual theft.

When Paola's suffering overwhelms her, pain pours out in terrible howling to which she gives way completely. As the days go by, she neither locks herself away from what has happened nor tries to deny it. In externalising her pain she looks to be more devastated than either her husband or daughter - but this is not the case. Rather, in releasing herself to suffering as it takes over her whole being, her weeping becomes a means of recovering the lost object in order to obtain the strength and help of others. She surrenders to the mourning process, which begins to prepare the way for the eventual change that will come over her when she finds it possible to resume her life and move on. Paola's process is a painful sign of emotional health as she reaches 
out not only for her lost son, but the other relationships that matter to her.

Giovanni is different and tries to cope alone, cutting himself off emotionally from his wife, daughter and clients. Mourning alone, as Furman stresses, is 'an almost impossible task' (1974: 114). His behaviour displays his ego's fierce attempt to preserve its fragility. He first tries to deaden his mind by overloading the senses in a solitary visit to a fairground which becomes to his ears and eyes a cacophonous pit of garish chaos mirroring his own inner state. Whereas Paola takes time off work to create the space to fall into despair and let her grieving find its way, he goes back to his patients at once. He immediately fills the space with distractions - the first line of defence of the ego being denial, splitting and repression. Bowlby suggests that 'An inability to mourn is an expression of an inability to tolerate being in a position of weakness and supplication' (1961: 319).

The doors to Giovanni's office become an obstacle. Irene goes there wanting to share sorrow and calls her father to breakfast. But faced with the blank barrier, she cannot bring herself to go through when he does not reply. She is left alone to cope with her distress as best she can.

Soon Giovanni begins to manifest obsessive behaviour. One evening when all three sit in Andrea's room, he plays over and over again a discordant few seconds from one of the lad's CDs. His actions indicate a repetition compulsion, a searching for an unremembered memory. The annoying cacophony distresses Paola and Irene, but he appears to be attempting to make a connection with an emotional, split-off part of himself that he cannot contact, in contrast with the others' ready access to their emotional lives. Blaming himself for the choice he made which led Andrea to his death, he tries to reverse time by repeatedly playing the fragment of music. He fantasises a revised memory of the Sunday morning phone conversation with Oscar. In his imagination he refuses his patient's request for a home visit and goes running with Andrea, which prevents his son from scuba diving. Then he convinces himself that Andrea's diving equipment must have failed - until Paola reminds him that it has been checked and found to be in good order. Longing to regain the lost object is integral to sadness and grief and Paola has managed to accept what cannot be controlled in life and take in that the incomprehensible happened: Andrea drowned in an accident after getting lost in an underwater cave and taking his tank off to find his way out. Giovanni must learn to remember consciously a part of himself he has forgotten in the process of working through his grief, which no less equals a restructuring of his character.

However, nothing reconciles Giovanni to the loss of his son. He remains locked in a state of that peculiar amalgam of anxiety, anger and despair which grief is. Edith Jacobson writes that the happier the relationship with the lost object has been the easier it is for the bereaved to experience sadness and the less does aggression intrude to create conflict and difficulty (in Bowlby, 1961: 327). Read superficially, this would imply that father and son were not at ease with each other - clearly overstating the case. For Giovanni the complicating factor is the complete failure of the omnipotent fantasies that, like many therapists, he has. The resultant guilt stokes an aggression which, though directed at the world around him, is actually aimed at himself. He will be able to experience his sadness and this aggression only when he breaks through his own defences.

Ultimately, as Bradshaw (2002) notes, the Sermontis have to endure their pain without convenient fantasies to fall back on, which makes The Son's Room all the more convincing. As Greg Mogenson reports, nothing weighs so heavily upon a mourner's heart than the passing of a life that has been incompletely lived. The more truncated the life, the more difficult the grieving for it in a depressive search for the meaning of that early death (1992:103). And as Oscar (of all people) will remark when he returns to therapy with Giovanni, the grief of parents who are predeceased by their child is almost beyond bearing. It hardly needs adding that Giovanni's circumstances as a psychoanalyst seriously compromise the essence of his work, namely his capacity to be fully present to the suffering of his clients. As we witnessed prior to the death of his son, the doors provided a symbolic function separating his happy family life from the psychic demands of his work. Moving back to work so quickly was his unconscious treatment plan to stay away from his own devastated life, evacuating his grief-stricken self in the troubled lives of his clients. How can his mind not be occupied by the command, 'Physician, heal thyself'? The remedy will require Giovanni to be present to his own pain and eventually seek out the strength and help of others.

For her part, Irene focuses intently on her school life and the basketball tournaments to which she has returned soon after Andrea's death. She has lost both her parents' presence during this time so returning 
to her friends and exterior life is both natural and necessary. Yet the untimely trauma is experienced 'as an incomprehensible and overwhelming assault that strikes at the core of the adolescent's intrapsychic and external world' (Sussillo, 2005: 499). Irene's activity is not enough either to ease or govern her suffering. Her rage bursts out on another Sunday afternoon when her team is playing away before a hostile crowd (her parents isolated in their sector of the stadium are her team's only supporters). When an opponent fouls her, Irene protests unavailingly and then starts a fight with the other girl that escalates into a messy ruckus both on field and off as she performs an Eric Cantona and attacks some of the razzing spectators. In effect, Irene is experiencing the loss of being psychically held by both parents who are understandably destabilised from the shock of losing Andrea. As Sussillo observes, 'When grief intrudes in bursts, the adolescent's experience in the absence of emotionally attuned others may be alarming, profoundly isolating and despairing,' (2005: 500). Many aspects of Irene's milieu are experienced as violently altered and irrevocably different, even though some external realities - her school, friends and activities - may look the same. However, she regains her life more swiftly than her parents, whose identity as parents has changed forever.

Communication between Giovanni and Paola approaches a nadir. He prowls their seemingly immaculate kitchen picking out items of crockery that are chipped or cracked. Lifting his favourite teapot, he remarks how well they had repaired it after it had been dropped. No sooner said than he deliberately shatters it in a furious gesture that enacts a painful reminder of what is broken beyond repair. His aggression intrudes a new, uncharacteristic dynamic into the marriage, a first indication Giovanni cannot contain his grief. Perhaps, as Bowlby suggests, a further increase in aggression that might lead to even stronger outbursts of anger is prevented by the memories of a happy past and of a previously rich self (1961: 327). Bowlby describes the behavioural sequence of mourning which demonstrates that Giovanni's anger, Paola's despair and Irene's protest all present normal reactions to loss. That sequence 'begins with anger and anxiety, proceeds through pain and despair and if fortune smiles, ends with hope. Both feeling and behaviour oscillate violently especially in the early phases of grief. Yearning, protest and rage alternate with blank mute despair' (1961: $330)$.

Mail arrives addressed to Andrea. Paola opens the envelope and reads a love letter from a girl with whom he had spent a single day at a summer camp. The deep emotion Paola feels in discovering an aspect of her son's life that she knew nothing about reveals two things about her grieving. The first is that Giovanni's own difficult mourning process has alienated Paola, moving her further into a depressive state. The second concerns the risk identified by Mogenson that an image of the dead person taken from the past may atrophy, with the consequent atrophying of the mourner (1992: 29-30). For both Paola and Irene, Arianna's letter regenerates Andrea's image. When the girl writes that his silences do not make other people feel awkward, they recognise something they had forgotten.

Giovanni, however, does not allow the process of renewal to commence. He remains locked to memories of his son on that last Sunday morning (mixing the actual past with wish fulfilment). When he suggests that rather than Paola phoning Arianna he should write a letter telling her about Andrea's death, that in part accords with his sensitive need to protect the girl as well as his need to control (an expression of his inability to tolerate being in a vulnerable position); but it also indicates that he is beginning to get stuck with his existing idea of Andrea as if (to use Mogenson's phrase) it were an image in a museum (Ibid.: 30). Paola gets it right, in saying, "You think talking about Andrea means losing something."

Rather like Bowlby, Elisabeth Kübler-Ross (1969) describes mourning as having five stages: denial; anger; bargaining and negotiation; depression; and acceptance. As Giovanni's fluctuation shows, it is a non-linear process involving a moving back and forth from one stage to another until the mourner has exhausted all need to move from one stage to another and finds him or herself in a new psychological place. Having oscillated between denial, anger and bargaining, Giovanni now sinks into the depressive state. When Paola talks about wanting to meet Arianna he intervenes to dissuade her, but she can no longer cope with his blocked obsessions and soon they are sleeping separately in the house.

Things have meantime been getting worse in Giovanni's practice and he realises that he can no longer face his patients with any conviction. A turning point comes when Oscar seeks Giovanni's endorsement of his belief that a positive attitude helps cancer sufferers like himself to fight off the disease. Rather than deflecting the issue by saying the belief is common but unproven, Giovanni coolly rebuts the notion, his once positive 
attitude lost in his private suffering. Whatever his medical knowledge of lung cancer may be, it is plain that Giovanni cannot separate self-blame from anger directed toward his patient for having pulled him away from his family that fateful Sunday. Giovanni seeks supervision from a colleague who addresses his counter transference toward Oscar. The other counsellor advises Giovanni to tell Oscar about his own emotion as grist to the mill in hopes of mobilising what now silently sits between them. But Giovanni cannot conceive of communicating his still too raw, unprocessed emotions.

Unable to do anything other than respond to the dominant impulse of the moment, Giovanni tells his clients that he must discontinue working with them. Faced with the necessity to find a new therapist, their reactions are intriguing. The indecisive woman (whom Giovanni has been offering techniques to help her adjust) accepts the challenge and decides to postpone further analysis until he resumes his practice. Oscar (to whom Giovanni has given no account of his feelings) has already made his decision and thanks his analyst before bringing the therapy to an end because everything has changed for him. Notwithstanding Giovanni's scepticism he intends to focus all his energy on making a physical recovery and expresses deep gratitude to Giovanni for helping him. However, the disturbed sex addict is nowhere near ready to cope with his therapist's absence from his life. Feeling completely abandoned, he screams abuse and in a violent rage starts smashing the office furnishings until Giovanni finally allows himself to hold him; at which point the other man lets go, sobs uncontrollably and hangs onto his therapist like a grown child.

We are left with the question how Giovanni himself will cope. He will lose his income, his profession and perhaps (as he and Paola silently acknowledge) his wife too; and at the root of all this lurks a grieving process so badly blocked that there is no obvious way for it to resume. Idle at home, he prepares an evening meal. But home is now too cold a place for the others and Paola stays on at her office desk working late while Irene chats to a friend in a bar. As Giovanni cooks a dish, it splits on the hob - an echo of his smashing the teapot, and perhaps the deepest hour of his depression. Yet at the time of this nadir, and before help arrives from an unexpected quarter, he goes to his son's favourite record store to buy a present for Andrea and asks for help in buying a CD that the boy would have liked. It is a moment of sweetness that at last marks a turning point when the mourning process begins to supplant unrelieved grief.

Meanwhile the strong urge to communicate with the unknown girl who had loved her son has not left Paola. Fed up with waiting for her prevaricating husband to write, she telephones Arianna. As Giovanni had foreseen, the unexpected news of Andrea's death delivered by his sobbing mother so shocks the girl that she hastens to bring the phone call to an end, swiftly declining Paola's invitation to visit or have further contact. However, Giovanni had not anticipated that the girl would not only be observant, passionate and subtle (as her letter had revealed) but she would also possess considerable emotional resilience. The Sermontis know nothing of that until without warning Arianna (Sofia Vigliar) arrives at their door. ${ }^{(2)}$ Now it is the turn of the adults to be shaken. At first they find it difficult to open their feelings to her but she has brought with her exuberant photos that Andrea had taken of himself in his bedroom. For Giovanni these pictures kick start the revitalising of his internalised image of his beloved son. For the whole family the fact that Arianna has come to see them brings comfort; but more than that, her presence is illuminating.

Arianna has called by for an hour or two only, interrupting a hitchhiking trip to France. She is travelling with a friend Stefano (Alessandro Ascoli). Clearly her life has moved forward and she has accepted and absorbed the loss of the boy she cared for. That of course is easier for a teenager whose romantic feelings are based on a single day and a passionate correspondence than for close family. Nevertheless her example points the way forward for the Sermontis - Giovanni in particular. Despite the fact that mourning is always experienced as a letting go, it is not, Mogenson writes, about getting rid of 'lost objects'. The mourning process does not rid us of our attachments but of our projections so that finally we see those we have lost for who they are (1992: 98). As a direct consequence, it also allows mourners to see themselves more clearly too.

It is this process that strengthens as in the evening Paola, Giovanni and Irene drive the young travellers to a service area on the autostrada. But no cars stop for the hitchhikers, so they all drive forward into the night, with Giovanni extending the journey far beyond his first target while the three teenagers sleep in the back seats. As they go on, his love for Paola and Irene reawakens and his affection for the young visitors deepens. Come the early morning light, they reach the Riviera with only the adults awake. Irene wakes up, 
astonished to find herself on the French border (edging, as it were, onto new psychological territory). She asks her parents rather fiercely if they have forgotten she has to attend training for her first game back with the team. Giovanni and Paola look at each other and their daughter, amused by her intensity, and begin to laugh.

When the incongruity of her irritation dawns on her, Irene joins in the laughter. The family are beginning to share their emotions again and the good feelings continue as they take breakfast with Arianna and Stefano. When the young travellers board a coach to continue their journey to Paris, the Sermontis wander onto the beach. As the film ends there is space between the three of them but they are relaxed, separate yet together. We are reminded of Nietzsche's vision of the tragic condition of humanity in which to live to the fullest is to build sandcastles passionately, all the time aware of the incoming tide.

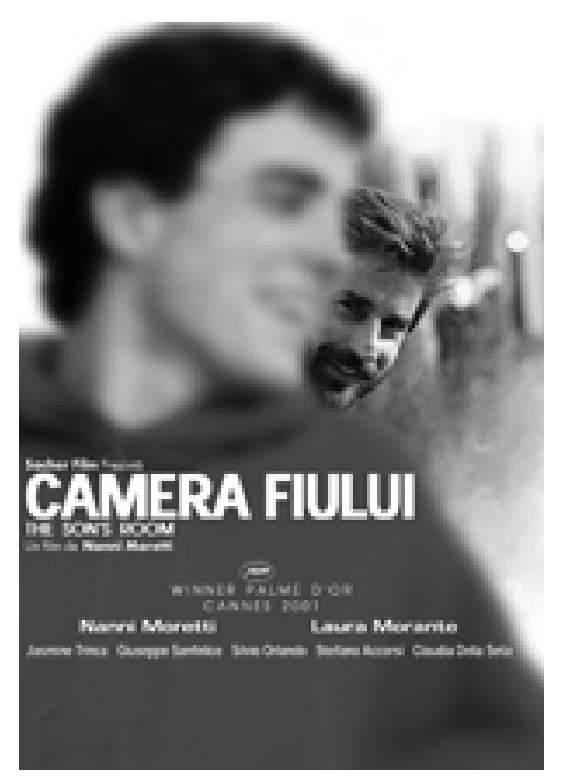

Figure 1: The Son's Room (publicity poster)

\section{Notes}

1. Mentalizing is the ability to understand oneself and others by inferring the mental states that lie behind overt behaviour (Peter Fonagy http://www.ucl.ac.uk/psychoanalysis/unit-staff/mentalization_bpd.htm accessed 31 May 2010). The term refers to the process by which people realize that having a mind mediates their experience of the world. It is an essential feature of emotional self-regulation and thus a core aspect of human social functioning. It allows individuals to 'make sense of' or understand themselves and others.

2. Ariadne (from whose name Arianna derives) was the figure in classical mythology who gave Theseus the ball of thread which enabled him to find his way out of the Labyrinth after he slew the monster.

\section{References}

Armstrong, Rod (2001), "The Son's Room," Reel.com

http://www.reel.com/movie.asp?MID=134214\&Tab=reviews\&buy=open\&CID=13\#tabs Accessed

August 2007.

Boeree, C. George (2002) 'A Bio-Social Theory of Neurosis'

http://webspace.ship.edu/cgboer/genpsyneurosis.html. Accessed 7 June 2010.

Bowlby, John (1961), 'Processes of Mourning,' The International Journal of Psychoanalysis 42, 317-40. 
Bradshaw, Peter (2002), 'The Son's Room,' The Guardian (15 February).

http://film.guardian.co.uk/News_Story/Critic_Review/Guardian_Film_of_the_week/0,650165,00.html accessed 3 August 2007.

French, Philip (2002), 'A Matter of Death and Life,' The Observer (17 February). http://film.guardian.co.uk/News_Story/Critic_Review/Observer_Film_of_the_week/0, „651369,00.html accessed 3 August 2007.

Furman, Erna (1974) A child's parent dies: Studies in childhood bereavement. (New Haven: Yale University Press).

Kübler-Ross, Elisabeth (1969), On Death and Dying. London: Tavistock Publications. Mogenson, Greg (1992), Greeting The Angels: An Imaginal View of the Mourning Process. Amityville, NY: Baywood Publishing.

Sussillo, Mary V. (2005), 'Beyond the Grave- Parental Loss: Letting Go and Holding On,' Psychoanalytic Dialogues, 15 (4): 499-527.

\section{Author Information}

John IZOD is Professor of Screen Analysis in the department of Film \& Media Studies, University of Stirling. He served as Dean of the Faculty of Arts, is a Founding Fellow of the Institute of Contemporary Scotland, and was elected a Fellow of the Royal Society for Arts in 2000. His books and articles include Reading the Screen; Hollywood and the Box Office; and The Films of Nicolas Roeg. His latest book is the Myth, Mind and the Screen: Understanding the Heroes of our Time (Cambridge, 2001).

Joanna DOVALIS, PhD, a practicing psychotherapist, is co-author of "Grieving, Therapy, Cinema and Kieślowski's Trois Couleurs: Bleu" in The San Francisco Jung Institute Library Journal 25, 3 (2006); "Trois Couleurs:Blanc" Jung Journal, 2, 3 (Summer 2008); and "Trois Couleurs: Rouge," Jung Journal, 2, 4, (Fall 2008). Her PhD thesis Cinema and Psyche: Individuation and the Postmodern Hero's Journey was accepted by Pacifica Graduate Institute in 2003. 